\title{
Poduzetnički inkubatori kao oblik poduzetnicke potporne institucije u Hrvatskoj
}

\section{Bojan Morić Milovanovic \\ Željka Tutic ${ }^{* *}$}

\author{
https://doi.org/10.31297/hkju.21.4.1 \\ UDK: $\quad 334.71: 338.246(497.5)$ \\ 338.246.027(497.5) \\ Original scientific paper / izvorni znanstveni rad \\ Received / primljeno: 14.10.2021. \\ Accepted/prihvaćeno: 14. 12. 2021.
}

Poduzetnički inkubatori jedan su od oblika potpornih institucija razvoja poduzetništva, pri čemu je njihova osnovna svrha poticanje poduzetničkoga okružja i osiguravanje preduvjeta razvoja poduzetnika na određenome području pružanjem raznih usluga. Poduzetnički inkubatori osnivaju se radi dinamiziranja lokalnog i regionalnog ekonomskog razvoja jer su im ciljna skupina poduzeća iz područja njihove županije ili grada. Svrha je ovog rada istražiti ulogu poduzetničkih inkubatora u pružanju potpore malim i srednjim poduzećima u Hrvatskoj. U radu se žele prikazati neke od osnovnih karakteristika poduzetničkih inkubatora, njihove odrednice i prakse poslovanja te istražiti i analizira-

* Dr. sc. Bojan Morić Milovanović, viši znanstveni suradnik, Institut za javne financije, Hrvatska (Senior research associate, Institute of Public Finance, Croatia, email: bojan. moric@ijf.hr).

ORCID: https://orcid.org/0000-0001-7676-6983 tic@mfin.hr).

** Željka Tutić, Ministarstvo financija (Ministry of Finance, Croatia, email: zeljka.tu- 
ti ponuda usluga koje inkubatori pružaju svojim stanarima. Također, u radu se nastoje ustanoviti osnovni ciljevi poslovanja, izvori financiranja te analizirati uspješnost inkubatora. Empirijski podaci prikupljeni su anketnim upitnikom na uzorku od 34 poduzetnička inkubatora, pri čemu je metoda deskriptivne statističke analize korištena radi pružanja potanka opisa trenutačnog stanja, karakteristika te poslovanja poduzetničkih inkubatora u Hrvatskoj.

Ključne riječi: poduzetnički inkubatori, potporne institucije, poduzetništvo, Hrvatska, lokalni i regionalni razvoj

\section{Uvod}

Poduzetništvo se smatra jednim od ključnih čimbenika u rastu, razvoju, stabilizaciji te održivosti gospodarstva. Također, poduzetništvo je snažan generator otvaranja novih radnih mjesta, transfera znanja te cjelokupna razvoja poslovanja. Za potporu poduzetničkih aktivnosti nužno je postojanje dobro organizirana sustava čiji je cilj privlačenje mladih i obrazovanih da postanu poduzetnici te pružanje kvalitetne potpore poduzetnicima početnicima u tranziciji od razvoja poslovne ideje do realizacije održiva poslovnog modela. Međutim, mnogim novoosnovanim poduzećima nedostaju ključni resursi nužni za uspješan razvoj kao što su financijski i intelektualni kapital te se suočavaju s većim zaprekama u poslovanju u odnosu na već etablirana srednje velika i velika poduzeća. Stoga su kao odgovor na navedeno poduzetnički inkubatori kao oblik poduzetničke potporne institucije institucijski okvir potpore poduzetnicima početnicima u razvoju perspektivna poslovnog pothvata.

CSES (2002) definira poduzetničke inkubatore kao organizacije koje ubrzavaju i sistematiziraju procese nastajanja uspješnih poduzeća pružanjem sveobuhvatne i integrirane potpore kao što su radni prostori, poslovna potpora, mogućnosti povezivanja i umrežavanja itd. Također, pružanjem raznih usluga po načelu „sve na jednome mjestu“ i smanjenjem fiksnih troškova, poduzetnički inkubatori znatno poboljšavaju izglede za opstanak i rast novoosnovanih poduzeća. Uspješan poduzetnički inkubator generira stalan protok novih poduzeća s iznadprosječnim potencijalom stvaranja novih radnih mjesta i rasta. Stoga, može se zaključiti da je osnovni cilj poduzetničkih inkubatora stvaranje uspješnih poduzeća, novih radnih mjesta te gospodarski rast i razvoj, pri čemu je bitno naglasiti da postoje 
različiti modeli poduzetničkih inkubatora ovisno o njihovim karakteristikama. Poduzetnički inkubatori jedan su od oblika povezivanja gospodarstva i javnoga sektora, a u Hrvatskoj se uglavnom javljaju kao rezultat županijskih inicijativa (Dragičević \& Obadić, 2006). Prema OECD-u (2019), poduzetnički inkubatori pomažu u povezivanju relevantnih dionika i stvaranju poduzetničkih mreža doprinoseći na taj način lokalnom i regionalnom gospodarskom razvoju. Sa svrhom razvoja lokalnih i regionalnih zajednica poduzetnički inkubatori omogućuju povezivanje javnog, privatnog i znanstvenog sektora, tzv. Triple Helix model (Bošnjak, 2011).

Prvi poduzetnički inkubatori u Republici Hrvatskoj osnivaju se 1991. godine u Rijeci, Sisku i Zagrebu na inicijativu ministarstva i poslovali su u sklopu velikih gospodarskih subjekata kao što su Brodogradilište Rijeka, Željezara Sisak te koncern Končar u Zagrebu (Bošnjak, 2011; Matić, 2019). Osnivanje poduzetničkih inkubatora u RH bilo je uglavnom stihijsko i počelo je prvo u razvijenijim županijama u kojima su sveučilišta prepoznala značenje inkubatora za poduzetnički razvoj (Bošnjak, 2011). Inkubatori se ne osnivaju u okviru određena nacionalnog programa za poticanje poduzetništva, već su uglavnom rezultat inicijativa na lokalnoj i regionalnoj razini. U Strategiji razvoja poduzetništva u Republici Hrvatskoj od 2013. do 2020. godine (2013) bilo je istaknuto da poduzetničke potporne institucije u Republici Hrvatskoj nisu geografski ravnomjerno rasprostranjene, što je potrebno poboljšati radi ravnomjerna regionalnog razvoja. $U$ istom dokumentu dalje se navodi da je u 2010. godini $u$ RH postojalo 88 poduzetničkih potpornih institucija, od čega 31 razvojna agencija, 16 poduzetničkih inkubatora, šest tehnoloških parkova i 35 poduzetničkih centara, a vezano uz njihovu koncentraciju u županijama, navodi se da su poduzetničke potporne institucije najviše koncentrirane u najvećim centrima RH, Zagrebu, Osijeku, Splitu i Rijeci, dok se u manje razvijenim županijama nalazi jedna do dvije potporne institucije, od kojih je jedna regionalna razvojna agencija.

Svrha je ovog rada istražiti ulogu poduzetničkih inkubatora u pružanju potpore sektoru malog i srednjeg poduzetništva u Republici Hrvatskoj. U radu se žele prikazati neke od osnovnih karakteristika poduzetničkih inkubatora, njihovih odrednica i praksi poslovanja te istražiti i analizirati ponudu usluga koje inkubatori pružaju svojim stanarima. Također, u radu se nastoje ustanoviti osnovni ciljevi poslovanja, izvori financiranja te analizirati uspješnost inkubatora. 


\section{Poduzetničke potporne institucije}

Poslovna inkubacija dinamičan je proces stvaranja poduzeća gdje inkubatori uslugama poslovne potpore, korištenjem poslovnih prostora, opremom te pristupom financiranju omogućuju rast novoosnovanim poduzećima u najkritičnijim fazama njihova razvoja (CSES, 2002). Nužno je razlikovati proces poslovne inkubacije od poduzetničkih inkubatora. Inkubator je poduzeće, a inkubacija proces ili programi kojima su podvrgnuta poduzeća stanari unutar inkubatora (OECD, 1997; Hacket \& Dillts, 2004). Bergek i Norrman (2008) navode da su inkubatori organizacije posvećene poduzećima u nastajanju, odnosno usmjereni su prije svega na poduzetnike početnike kojima pomažu razviti se u održiva poduzeća tako što im pružaju zajedničku infrastrukturu, usluge, poslovnu potporu te mogućnosti umrežavanja.

Uz poduzetničke inkubatore postoje i razne druge institucije specijalizirane za pružanje potpore malim i srednjim poduzećima, a koje su prikazane u Tablici 1. Prema Zakonu o unapređenju poduzetničke infrastrukture iz 2013., tu se ubrajaju: županijske i lokalne razvojne agencije kao i razvojne agencije za određene djelatnosti, poduzetnički centri, poslovni inkubatori, odnosno poduzetnički inkubatori i inkubatori za nove tehnologije, poduzetnički akceleratori, poslovni parkovi, znanstveno-tehnološki parkovi i centri kompetencije. Bošnjak (2011) navodi da sve te potporne institucije imaju iste ciljeve koji se odnose na stvaranje radnih mjesta i konkurentnih proizvoda te da ih nije uvijek jednostavno razlikovati.

\section{Tablica 1. Vrste poduzetničkih potpornih institucija}

Oblici poduzetničkih potpornih institucija

\begin{tabular}{|l|l|}
\hline Razvojne agencije & $\begin{array}{l}\text { Imaju za cilj operativno provođenje mjera za razvoj gospodarstva } \\
\text { i poduzetništva na lokalnoj (regionalnoj) i nacionalnoj razini te su } \\
\text { usmjerene na privlačenje investicija, iniciranje i realizaciju projekata. }\end{array}$ \\
\hline $\begin{array}{l}\text { Poduzetnički } \\
\text { centri }\end{array}$ & $\begin{array}{l}\text { Registrirane pravne osobe koje imaju za cilj operativno provođenje } \\
\text { mjera za poticanje poduzetništva u sredinama u kojima su osnovani } \\
\text { djelujući kao središta stručne i edukativne potpore poduzetnicima. }\end{array}$ \\
\hline $\begin{array}{l}\text { Poduzetnički } \\
\text { inkubatori }\end{array}$ & $\begin{array}{l}\text { Registrirane pravne osobe za pružanje potpore poduzetnicima u } \\
\text { ranoj fazi razvoja poduzetničkih projekata nizom poslovnih usluga } \\
\text { i resursa, uključujući poslovne (radne) prostore po povoljnijim uv- } \\
\text { jetima za poduzetnike početnike. }\end{array}$ \\
\hline $\begin{array}{l}\text { Inkubatori za } \\
\text { nove tehnologije }\end{array}$ & $\begin{array}{l}\text { Tematski su usmjereni na inovativno poduzetništvo i inkubacijskim } \\
\text { programima pružaju resurse i profesionalne usluge novoosnovanim } \\
\text { inovativnim poduzećima. }\end{array}$ \\
\hline
\end{tabular}




\begin{tabular}{|l|l|}
\hline $\begin{array}{l}\text { Poduzetnički } \\
\text { akceleratori }\end{array}$ & $\begin{array}{l}\text { Registrirane pravne osobe za pružanje usluga potpore poduzetnici- } \\
\text { ma u fazi razvoja i širenja poslovanja. }\end{array}$ \\
\hline Poslovni parkovi & $\begin{array}{l}\text { Registrirane pravne osobe usmjerene na privlačenje investicija i koje } \\
\text { raspolažu fizičkim prostorom i resursima za smještaj poduzetnika na } \\
\text { komercijalnoj osnovi. }\end{array}$ \\
\hline $\begin{array}{l}\text { Znanstveno- } \\
\text { tehnološki parkovi }\end{array}$ & $\begin{array}{l}\text { Cilj im je komercijalizacija znanstvenih rezultata poticanjem surad- } \\
\text { nje znanstvenika i gospodarstvenika. }\end{array}$ \\
\hline $\begin{array}{l}\text { Centri kompe- } \\
\text { tencije }\end{array}$ & $\begin{array}{l}\text { Specijalizirani poslovni subjekti koji provode razvojna i primijenjena } \\
\text { istraživanja i usmjereni su na njihovu komercijalizaciju te na jačanje } \\
\text { intelektualnog vlasništva unutar specifičnih tematskih područja i } \\
\text { grana kompetencije. }\end{array}$ \\
\hline
\end{tabular}

Izvor: autori.

CSES (2002) i Medić (2004) pružaju distinkciju između tradicionalnih inkubatora i inkubatora "nove ekonomije“, gdje prvi imaju za cilj ekonomski razvoj promoviranjem poduzetništva i stvaranjem radnih mjesta, dok potonji predstavljaju uglavnom virtualne inkubatore koji mogu, ali i ne moraju nuditi uslugu poslovnog prostora, pri čemu su usredotočeni na pružanje potpore visokotehnološkim i internetskim poduzećima te su ih uglavnom osnovale privatne kompanije. Inkubatori nove ekonomije svoje usluge naplaćuju prihodom ostvarenim od sredstava uloženih u razvoj stanara inkubatora, za razliku od tradicionalnih inkubatora koji se oslanjaju na sredstva od subvencioniranog zakupa poslovnog prostora (Medić, 2004).

Poseban su oblik inkubatora i inkubatori kojima je cilj pomoći u razvoju poduzetništva određenog dijela stanovništva, primjerice mladih ili žena. Shalaby (2007) naziva tu vrstu inkubatora inkubatorima za osnaživanje jer su usredotočeni na korisnike kao što su pripadnici manjina ili žene i uglavnom su smješteni u nerazvijenijim regijama da pridonesu njihovoj revitalizaciji i rastu. Korisnici usluga poduzetničkih inkubatora i one su skupine kojima je otežano počinjanje poduzetničkog pothvata zbog razloga koji mogu uključivati stupanj obrazovanja, godine poslovnog iskustva te nacionalnu ili rasnu pripadnost (Medić, 2004; OECD, 2019). Kao oblik potpore poduzetništva mladih uspostavljaju se studentski poduzetnički inkubatori čija su ciljna skupina studenti kojima se pruža mogućnost realizacije njihovih poslovnih ideja. Studenti mogu imati dobre i inovativne ideje koje potencijalno mogu doprinijeti poticanju poduzetništva i smanjenju nezaposlenosti ako im se poduzetničkim inkubatorima pruži potrebna logistička i financijska potpora (Li, Ahmed, Qalati, Khan \& Naz, 2020). 
Često se u literaturi pojam znanstveno-tehnološkog parka i pojam inkubatora za visoke tehnologije navode kao alternativni pojmovi (Zekić \& Bukovac, 2008; OECD, 2019). Zekić i Bukovac (2008) navode da se tehnološki parkovi osnivaju u više organizacijskih oblika, a svaki organizacijski oblik ima određene specifičnosti, od znanstveno-tehnološkog parka čija je glavna funkcija razvoj novih proizvoda i tehnologija, preko inkubatorskog parka čiji je cilj razvoj malih i srednjih poduzeća utemeljenih na visokim tehnologijama, sve do tehnoloških centara koji za cilj imaju organizaciju te realizaciju istraživačkih i razvojnih industrijskih projekata. Inkubator za visoke tehnologije prema toj bi definiciji bilo moguće promatrati kao sastavni dio tehnološkog parka. Osnivanje takvih inkubatora moguće je pri sveučilištima, istraživačkim centrima ili drugim ustanovama visokog obrazovanja, a koje uspostavljaju tijesnu suradnju s tehnološkim inkubatorom. Medić (2004) smatra da osnivanje inkubatora u suradnji s obrazovnim i istraživačkim institucijama može znatno podupirati razvoj poduzetničkog pothvata, posebno ako su djelatnosti poduzeća stanara vezane uz napredne tehnologije. Nerijetko se inkubatori uspostavljaju upravo u blizini sveučilišta ili veleučilišta, tehnološkog parka ili industrijske zone (Pace, 2001). Pri visokoškolskim ustanovama uspostavljaju se studentski poduzetnički inkubatori kao jedan od alata poduzetničke edukacije, pri čemu Čizmadija i Stanković (2011) smatraju da studentski poduzetnički inkubatori doprinose: (i) poticanju poduzetničkog načina razmišljanja studenata, (ii) unaprjeđenju suradnje i umrežavanja odgojno-obrazovnih ustanova i znanstveno-istraživačkih institucija s gospodarskim subjektima, (iii) prenošenju znanja kroz mentorski rad te poticanju studenata za osnivanje, vođenje i upravljanje malih poduzeća te (iv) financijsku, tehničku i savjetodavnu potporu u osnivanju vlastitih poduzeća. Na području Republike Hrvatske trenutačno djeluje 12 studentskih poduzetničkih inkubatora prikazanih u Tablici 2., pri čemu su četiri studentska poduzetnička inkubato$\mathrm{ra}^{1}$ upisana u Jedinstveni registar poduzetničke infrastrukture.

${ }^{1}$ Upisani studentski poduzetnički inkubatori jesu: Studentski poduzetnički inkubator Visoke poslovne škole PAR, BIZ-poduzetnički inkubator, CTT inkubator te DigiBoost d. o. o. koji trenutačno djeluje pod nazivom Algebra LAB. 
Tablica 2. Studentski poduzetnički inkubatori u $R H$

\begin{tabular}{|l|l|c|}
\hline \multicolumn{1}{|c|}{ Naziv inkubatora } & \multicolumn{1}{|c|}{ Visokoškolska ustanova } & $\begin{array}{c}\text { Godina } \\
\text { osnivanja }\end{array}$ \\
\hline CTT & $\begin{array}{l}\text { Fakultet strojarstva i brodogradnje } \\
\text { u Zagrebu }\end{array}$ & 1996. \\
\hline BIZ-poduzetnički inkubator & Europska poslovna škola u Zagrebu & 2008. \\
\hline Studentski poduzetnički inkubator & Ekonomski fakultet u Zagrebu & 2009. \\
\hline VERN start-up inkubator & VERN u Zagrebu & 2009. \\
\hline $\begin{array}{l}\text { Studentski poduzetnički inkubator } \\
\text { Visoke poslovne škole PAR }\end{array}$ & Visoka poslovna škola PAR u Rijeci & 2011. \\
\hline $\begin{array}{l}\text { Studentski poduzetnički inkubator } \\
\text { VUPI }\end{array}$ & $\begin{array}{l}\text { Veleučilište „Lavoslav Ružička“ u } \\
\text { Vukovaru }\end{array}$ & 2013. \\
\hline $\begin{array}{l}\text { Studentski poduzetnički inkubator } \\
\text { SPIN }\end{array}$ & Fakultet ekonomije i turizma u Puli & 2013. \\
\hline Studentski inkubator & Ekonomski fakultet u Osijeku & 2014. \\
\hline Algebra LAB & Algebra u Zagrebu & 2014. \\
\hline $\begin{array}{l}\text { Studentski poduzetnički inkubator } \\
\text { „AKTIVA“ }\end{array}$ & Veleučilište u Požegi & 2014. \\
\hline Studentski poduzetnički inkubator & Ekonomski fakultet u Splitu & 2015. \\
\hline $\begin{array}{l}\text { SPOCK Studentski start-up inkuba- } \\
\text { tor }\end{array}$ & $\begin{array}{l}\text { Fakultet elektrotehnike i } \\
\text { računarstva u Zagrebu }\end{array}$ & 2016. \\
\hline
\end{tabular}

Izvor: autori, prema podacima s mrežnih stranica studentskih inkubatora.

\section{Poduzetnički inkubatori kao oblik poduzetničke potporne institucije}

Poduzetnički inkubatori ubrajaju se u poduzetničke potporne institucije. Prema Zakonu o unapređenju poduzetničke infrastrukture iz 2013., koji obuhvaća sustav poduzetničkih zona i poduzetničkih potpornih institucija unutar Republike Hrvatske, poduzetnički inkubatori registrirane su pravne osobe koje „pružaju podršku uspješnom razvoju poduzetništva kroz poslovne usluge i resurse za poduzetnike, uključujući poslovne (radne) prostore po povoljnijim uvjetima za poduzetnike početnike." (čl. 4.). Pre- 
ma podacima iz Jedinstvenog registra poduzetničke infrastrukture, vidljivo je da se u odnosu na podatke iz Strategije razvoja poduzetništva u Republici Hrvatskoj (2013) povećao broj poduzetničkih potpornih institucija i poboljšana je njihova regionalna rasprostranjenost u skladu sa strateškim ciljem jačanja institucija koje pružaju potporu poduzetnicima. Jedinstveni registar poduzetničke infrastrukture obuhvaća 40 poduzetničkih inkubatora. Najveći broj nalazi se u Gradu Zagrebu, Istarskoj županiji i Osječkobaranjskoj županiji, dok u ostalim županijama nalazimo jedan do tri poduzetnička inkubatora. Osnivači su poduzetničkih inkubatora jedinice lokalne i područne (regionalne) samouprave (JLPRS), odnosno županije, gradovi i općine, a među osnivačima nalazimo i sveučilišta te u manjem broju i privatna poduzeća. Inkubatori su u najvećem dijelu potpuno u vlasništvu jedinica lokalne i regionalne samouprave, a suvlasnici mogu biti i sveučilišta, privatna poduzeća, udruge i banke. Oni se, uz poduzetničke zone i druge poduzetničke potporne institucije (razvojne agencije, poduzetnički centri, znanstveno-tehnološki parkovi, centri kompetencija i slobodne zone), ističu u svojoj ulozi poticanja poduzetničkoga okružja i osiguravanja potrebnih preduvjeta za razvoj poduzetnika na određenome području pružanjem savjetodavnih usluga, poslovnoga prostora, informacija i niza drugih usluga. Tablica 3. nudi detaljniji prikaz vrsta poduzetničkih inkubatora.

Opći su ciljevi poduzetničkih inkubatora smanjiti izglede za propadanje start-up poduzeća i povećati njihove izglede za opstanak na tržištu, potaknuti osnivanje novih poduzeća, pružiti poslovne, administrativne, edukacijske i druge usluge svojim članovima i slično (Tupek \& Ćorić, 2018). Poduzetnički inkubatori osnivaju se i radi dinamiziranja lokalnog i regionalnog ekonomskog razvoja jer su ciljna skupina inkubatora poduzeća iz područja njihove županije ili grada koja zadovoljavaju kriterije smještaja u inkubatoru. Mogu postati rasadnici dobrih poduzetničkih ideja i pothvata te su učinkovit instrument za promoviranje poduzetničkih aktivnosti (Bošnjak, 2011). Sredstva za poslovanje poduzetničkih inkubatora osiguravaju gradovi ili županije kako bi se unaprijedili uvjeti za poslovanje poduzetnika u njihovim sredinama. Prema CSES-u (2002) posebni ciljevi poduzetničkih inkubatora mogu uključivati gospodarski razvoj, stvaranje uspješnih poduzeća, otvaranje radnih mjesta, pomoć pri transferu tehnologije, pomoć sveučilištima u komercijalizaciji istraživanja, povećanje broja stanara koji napuštaju inkubator te ostvarivanje profita. Također, jedan od ciljeva poduzetničkih inkubatora trebao bi se odnositi i na postizanje financijske samoodrživosti, bilo prikupljanjem naknada za zakup prostora i za pružanje usluge ili prihodima iz ostalih izvora financiranja kao što su bespovratna sredstva iz EU-fondova. 
Tupek i Čorić (2018) smatraju da inkubatori nude različite vrste usluga koje su potrebne poduzetnicima početnicima, međutim jednako tako smatraju i da je potrebno unaprijediti pružanje određenih vrsta usluga, posebice usluge umrežavanja i povezivanja s investitorima, usluge poslovnoga mentorstva, povećanje broja edukacija namijenjenih razvoju specifičnih vještina, pomoć u prodaji i izvozu te pomoć pri izradi i implementaciji projekata financiranih sredstvima EU-a. Naglasak na pojedinoj skupini usluga ovisi i o vrsti inkubatora, pa će tako tehnološki inkubatori u usporedbi s tradicionalnim poduzetničkim inkubatorima obično veći naglasak staviti na određenu vrstu usluga kao što su zaštita intelektualnog vlasništva, pristup financiranju i marketing (OECD, 1997). Također, poduzetnički inkubatori prihvaćaju pravilnike u kojima su obično definirani kriteriji dodjele zakupa poslovnog prostora, kriteriji izlaska iz prostora inkubatora, vrste usluga te način korištenja uslugom (Bošnjak, 2011).

Razlikovanje inkubatora prema tome imaju li profitni ili neprofitni karakter također je važno za razumijevanje načina kako se inkubatori osnivaju i kako funkcioniraju. Neprofitne inkubatore osnivaju i u najvećem dijelu financiraju javni osnivači, dok se profitni inkubatori financiraju i iz privatnih izvora (Tang i sur., 2014; Musterós Batlle, 2016). Prema Dutt i suradnicima (2016), razlike u sponzorima inkubatora znatno su povezane s vrstama usluga koje inkubatori pružaju poduzećima stanarima, i to na sljedeći način: privatni inkubatori stavljaju naglasak na pružanje financijskih usluga, sveučilišni inkubatori naglašavaju pružanje infrastrukturnih usluga i usluga savjetovanja, dok javni neprofitni inkubatori pružaju različite vrste usluga bez posebne specijalizacije.

Zajednička je karakteristika poduzetničkih inkubatora osiguravanje poslovnog prostora poduzetnicima početnicima, pri čemu često primaju i ostala poduzeća koja nemaju status poduzetnika početnika. ${ }^{2}$ Subvencioniran zakup poslovnog prostora uglavnom je na raspolaganju poduzetnicima početnicima koji su u prvoj godini poslovanja u inkubatoru vrlo često i oslobođeni plaćanja zakupa, dok u preostalim godinama plaćaju cijenu koja je znatno niža od tržišne cijene (Bošnjak, 2011). Vrijeme boravka u inkubatoru prema pravilnicima ograničeno je do maksimalno pet godina, nakon čega se od poduzeća očekuje izlazak iz inkubatora i oslobađa se

2 Poduzetnici početnici u pravilnicima inkubatora definiraju se kao poduzetnici koji su u trenutku podnošenja zahtjeva za prijam u inkubator upisani u odgovarajući registar (obrtni registar, sudski registar i drugi) najviše do tri godine kao i osobe koje nisu registrirane, ali namjeravaju obaviti registraciju u roku od jednog mjeseca od dana primitka u poslovni prostor inkubatora. 
mjesto za druge stanare. Dodana vrijednost smještaja u inkubatoru dostupnost je usluga poslovnog savjetovanja koje su stanarima omogućene u najvećem broju slučajeva bez plaćanja naknade. Inkubatori se stoga osnivaju u blizini poduzetničkih centara, razvojnih agencija i poduzetničkih parkova, u sinergiji s kojima je stanarima dostupna stručna i savjetodavna pomoć. Također, osim usluge inkubacije, inkubatori u RH nude i usluge predinkubacije i postinkubacije. $U$ fazi predinkubacije, koja je u pravilu ograničena na šest ili više mjeseci, osigurava se radni prostor i potpora poduzetnicima početnicima koji su tek registrirali poduzeće ili su u procesu registracije poduzeća ili obrta. Postinkubacija se definira kao razdoblje u kasnijoj fazi rasta i razvoja poduzetnika u inkubatoru i omogućava poduzetniku razvoj novih proizvoda, usluga i projekata, internacionalizaciju poslovanja te pomoć pri traženju dodatnih izvora financiranja. Postinkubacija je također ograničena u pravilu do najviše pet godina. Također, inkubatori omogućuju poduzetnicima i programe virtualne inkubacije ili tzv. "off-inkubacije“ bez naknade ako im nije potreban poslovni prostor, pri čemu im je i dalje dostupna poslovna potpora.

\section{Tablica 3. Vrste poduzetničkih inkubatora}

\begin{tabular}{|c|c|}
\hline \multicolumn{2}{|r|}{ Vrste poduzetničkih inkubatora } \\
\hline Predinkubatori & $\begin{array}{l}\text { Osiguravaju trening, poslovno savjetovanje kao i radni prostor te } \\
\text { opremu za razvoj poslovne ideje. }\end{array}$ \\
\hline $\begin{array}{l}\text { Sveučilišni inku- } \\
\text { batori }\end{array}$ & $\begin{array}{l}\text { Posluju u sklopu sveučilišta ili istraživačkih centara i usmjereni su } \\
\text { na pružanje potpore studentima i akademicima za njihove poslovne } \\
\text { ideje, a mogu biti uspostavljeni i kao spin-off istraživačko-razvojnih } \\
\text { aktivnosti sveučilišta kao i u suradnji s tvrtkama iz privatnog sektora. }\end{array}$ \\
\hline $\begin{array}{l}\text { Višesektorski } \\
\text { inkubatori }\end{array}$ & $\begin{array}{l}\text { Pružaju sve usluge od predinkubacijske do postinkubacijske faze i } \\
\text { osiguravaju potporu svima s izvedivom poslovnom idejom. }\end{array}$ \\
\hline $\begin{array}{l}\text { Specijalizirani } \\
\text { inkubatori }\end{array}$ & $\begin{array}{l}\text { Pružaju sve usluge od predinkubacijske do postinkubacijske faze i } \\
\text { osiguravaju potporu svima s izvedivom poslovnom idejom, unutar } \\
\text { određenog sektora, npr. poljoprivreda ili informacijsko-komunikaci- } \\
\text { jska tehnologija. }\end{array}$ \\
\hline Poslovni hoteli & $\begin{array}{l}\text { Pružaju poslovni prostor i česti su u velikim gradovima te mogu } \\
\text { organizirati i radionice za umrežavanje poduzeća. }\end{array}$ \\
\hline $\begin{array}{l}\text { Korporacijski } \\
\text { inkubatori }\end{array}$ & $\begin{array}{l}\text { Korporativni pothvati koji investiraju u nova poduzeća i start-upove } \\
\text { imaju cilj integrirati ih u vlastiti portfelj. }\end{array}$ \\
\hline
\end{tabular}

Izvor: autori, prema OECD-u (2019). 


\section{Istraživanje poduzetničkih inkubatora u Hrvatskoj}

U ovom poglavlju pružit će se detaljan opis istraživačkih metoda korištenih u provedbi empirijskog dijela istraživanja. Nadalje, pružit će se opis uzorka, prikazat će se osnovna obilježja ispitanika te osnovne karakteristike poduzetničkih inkubatora. Također, pružit će se iscrpan opis te rezultati analize osnovnih ciljeva inkubatora, usluga koje inkubatori pružaju te uspješnost inkubatora.

\subsection{Upitnik, uzorak i metode istraživanja}

Empirijski podaci prikupljeni su elektroničkim anketnim upitnikom izrađenim u obliku Google obrasca tijekom ožujka i travnja 2021. godine te poslanog na elektroničku poštu 62 poduzetnička inkubatora, pri čemu je 40 poduzetničkih inkubatora identificirano u Jedinstvenome registru poduzetničke infrastrukture ${ }^{3}$, dok se preostala 22 inkubatora ne nalaze u njemu. Elektronički anketni upitnik poslan je na e-adrese poduzetničkih inkubatora navedenih u Jedinstvenom registru poduzetničke infrastrukture ili na internetskim stranicama inkubatora. Stopa povrata iznosi 54,8 \% s obzirom na to da su zaprimljena 34 odgovara od ukupnog broja od 62 inkubatora kojima je upućen anketni upitnik. Za potrebe analize prikupljenih podataka korištena je metoda deskriptivne statističke analize jer je cilj ovog rada pružiti detaljan opis trenutačnog stanja, karakteristika te poslovanja poduzetničkih inkubatora u Republici Hrvatskoj. Cilj rada nije prikazati međusobne odnose ili međusoban utjecaj promatranih varijabli. Anketni upitnik sastoji se od ukupno 26 pitanja podijeljenih u šest glavnih dijelova: (i) osnovne informacije o ispitaniku; (ii) općenite informacije o inkubatoru; (iii) vrste inkubatora i ciljevi; (iv) usluge inkubatora; (v) specifične informacije o inkubatoru i (vi) pokazatelji uspješnosti inkubatora. U prvome dijelu anketnog upitnika prikupljene su općenite informacije o sudionicima istraživanja i postavljena su pitanja o njihovoj dobi, spolu, obrazovanju, radnome mjestu i radnome stažu u poduzetničkome inkubatoru. U drugome dijelu anketnog upitnika prikupljene su općenite informacije o poduzetničkim

3 U Republici Hrvatskoj pri nadležnome ministarstvu za poduzetništvo uspostavljen je Jedinstveni registar poduzetničke infrastrukture u kojem su evidentirani svi subjekti poduzetničke infrastrukture, uključujući i inkubatore. U registru se nalazi 40 aktivnih inkubatora koji su korisnici potpora, poticajnih mjera, darovnica ili povlastica odobrenih od nadležnoga ministarstva ili drugih tijela iz RH, Europske unije, odnosno međunarodnih tijela. 
inkubatorima vezano za njihovu lokaciju, razdoblje kad su uspostavljeni, broj poduzeća stanara te broj zaposlenika. U trećem dijelu sadržana su pitanja o vrsti inkubatora i ciljevima. $U$ četvrtom su dijelu anketnog upitnika prikupljene informacije o osnovnim uslugama koje inkubator pruža svojim stanarima. Zatim su u petome dijelu upitnika prikupljene informacije o razlozima zbog kojih poduzeća napuštaju inkubator, tržišnome fokusu inkubatora, kriterijima selekcije poduzeća i sponzorima inkubatora. U zadnjem dijelu upitnika sadržana su pitanja o osnovnim pokazateljima uspješnosti inkubatora.

Tablica 4. daje prikaz osnovnih demografskih obilježja ispitanika, pri čemu je bitno izdvojiti da su ispitanici u najvećem broju voditelji inkubatora ili direktori (70,6\%), u dobnoj skupini od 30 do 39 godina $(41,2$ \%), u radnom odnosu od dvije do četiri godine $(38,2 \%)$ te više ili visoke razine obrazovanja $(55,9 \%)$. Ovim istraživanjem nije traženo područje obrazovanja ispitanika, međutim u literaturi se može pronaći da voditelji inkubatora uglavnom posjeduju znanja iz područja financija, upravljanja ljudskim resursima ili marketinga (CSES, 2002).

Tablica 4. Osnovna obiliežja ispitanika

\begin{tabular}{|c|c|c|}
\hline Osnovna obilježja ispitanika & $\mathbf{N}$ & $\%$ \\
\hline \multicolumn{3}{|l|}{ Dob } \\
\hline manje od 20 godina & 0 & $0 \%$ \\
\hline 20-29 godina & 5 & $14,7 \%$ \\
\hline 30-39 godina & 14 & $41,2 \%$ \\
\hline 40-49 godina & 5 & $14,7 \%$ \\
\hline više od 50 godina & 10 & $29,4 \%$ \\
\hline \multicolumn{3}{|l|}{ Spol } \\
\hline $\mathrm{M}$ & 10 & $29,4 \%$ \\
\hline$\check{Z}$ & 24 & $70,6 \%$ \\
\hline \multicolumn{3}{|l|}{ Obrazovanje } \\
\hline srednje obrazovanje & 0 & $0 \%$ \\
\hline više i visoko & 19 & $55,9 \%$ \\
\hline magisterij & 12 & $35,3 \%$ \\
\hline doktorat & 3 & $8,8 \%$ \\
\hline \multicolumn{3}{|l|}{ Radno mjesto } \\
\hline voditelj inkubatora / direktor & 24 & $70,6 \%$ \\
\hline stručni suradnik / voditelj projekata / konzultant & 8 & $23,5 \%$ \\
\hline administrator & 2 & $5,9 \%$ \\
\hline Godine zaposlenja & & \\
\hline
\end{tabular}




\begin{tabular}{|c|c|c|}
\hline manje od 1 godine & 4 & $11,8 \%$ \\
\hline od 2 do 4 godine & 13 & $38,2 \%$ \\
\hline od 5 do 9 godina & 9 & $26,5 \%$ \\
\hline više od 10 godina & 8 & $23,5 \%$ \\
\hline Ukupno & 34 & $100 \%$ \\
\hline
\end{tabular}

Izvor: autori.

\subsection{Osnovne karakteristike poduzetničkih inkubatora}

Iz Grafikona 1. vidljivo je da su poduzetnički inkubatori prisutni u gotovo svim hrvatskim županijama. Od inkubatora koji su sudjelovali u istraživanju, najveći broj dolazi iz Primorsko-goranske županije $(\mathrm{N}=4,11,7$ \%). Pet županija ima po tri inkubatora, a to su: Koprivničko-križevačka, Bjelovarsko-bilogorska, Požeško-slavonska, Istarska i Osječko-baranjska županija, dok u trima županijama, odnosno u Varaždinskoj, Virovitičkopodravskoj i Dubrovačko-neretvanskoj, te u Gradu Zagrebu dolaze dva inkubatora. Iz ostalih županija dolazi svega jedan inkubator, a to su: Zagrebačka, Krapinsko-zagorska, Sisačko-moslavačka, Ličko-senjska, Zadarska, Vukovarsko-srijemska te Splitsko-dalmatinska županija (Grafikon 1.).

Grafikon 1. Broj inkubatora po županijama

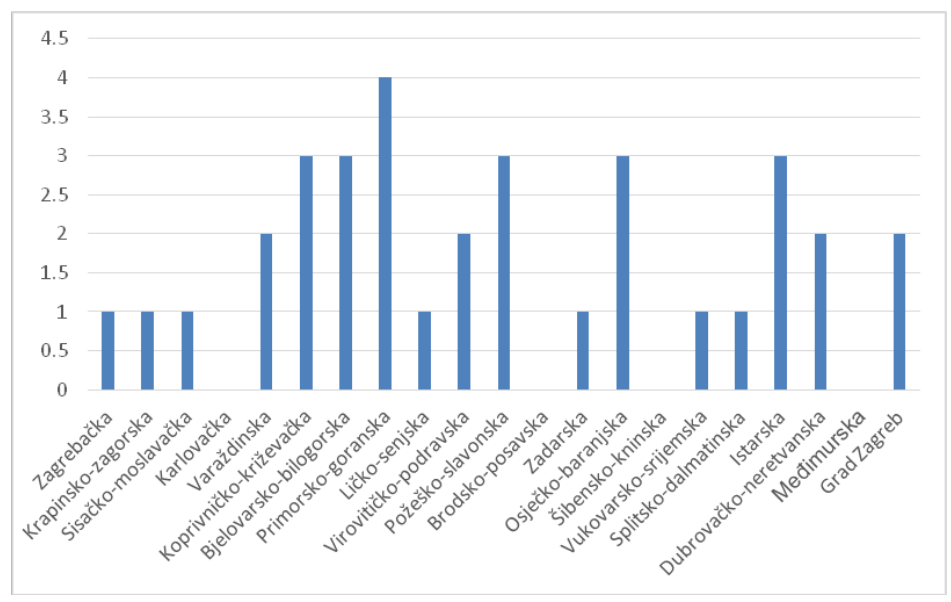

Izvor: autori.

Tablica 5. pruža prikaz osnovnih obilježja promatranih poduzetničkih inkubatora, pri čemu je vidljivo da je većina inkubatora uspostavljena nakon 2011. godine (64,7\%), dok je svega jedan inkubator uspostavljen do 2000. 
godine, a 32,4 \% od 2000. do 2010. godine. Stoga se može zaključiti da su poduzetnički inkubatori u Republici Hrvatskoj relativno noviji fenomen, pri čemu se porast broja inkubatora događa nešto kasnije nego u ostalim europskim zemljama s obzirom na izvore financiranja osnivanja inkubatora iz europskih pretpristupnih te europskih strukturnih i investicijskih fondova (CSES, 2002; Musterós Batlle, 2016).

Poduzetnički inkubatori većinom imaju do pet zaposlenika (55,9 \%), prema specijalizaciji prevladavaju višesektorski inkubatori $(76,5 \%)$ te se klasificiraju kao neprofitni (58,8 \%). Nadalje, u najvećem se broju promatranih poduzetničkih inkubatora (41,2 \%) nalazi više od 20 poduzeća, pri čemu je bitno napomenuti da se u EU-u broj od 20 poduzeća smatra optimalnim brojem poduzeća po inkubatoru (CSES, 2002).

Tablica 5. Osnovna obilježja inkubatora

\begin{tabular}{|c|c|c|}
\hline Osnovna obilježja inkubatora & $\mathrm{N}$ & $\%$ \\
\hline \multicolumn{3}{|l|}{ Godine osnivanja } \\
\hline 1991. - 2000 & 1 & $2,9 \%$ \\
\hline 2001. - 2010 . & 11 & $32,4 \%$ \\
\hline 2011. - 2021 & 22 & $64,7 \%$ \\
\hline \multicolumn{3}{|l|}{ Broj poduzeća } \\
\hline 1 do 5 & 6 & $17,6 \%$ \\
\hline 6 do 10 & 9 & $26,5 \%$ \\
\hline 11 do 15 & 4 & $11,8 \%$ \\
\hline 16 do 20 & 1 & $2,9 \%$ \\
\hline više od 20 & 14 & $41,2 \%$ \\
\hline \multicolumn{3}{|l|}{ Broj zaposlenika } \\
\hline 1 do 5 & 19 & $55,9 \%$ \\
\hline 6 do 10 & 6 & $17,6 \%$ \\
\hline više od 10 & 9 & $26,5 \%$ \\
\hline \multicolumn{3}{|l|}{$\mathrm{Ne} /$ profitni } \\
\hline neprofitni & 20 & $58,8 \%$ \\
\hline profitni & 14 & $41,2 \%$ \\
\hline \multicolumn{3}{|l|}{ Specijalizacija } \\
\hline specijalizirani & 8 & $23,5 \%$ \\
\hline višesektorski & 26 & $76,5 \%$ \\
\hline Ukupno & 34 & $100 \%$ \\
\hline
\end{tabular}

Izvor: autori. 


\subsection{Osnovni ciljevi inkubatora}

Analizirajući glavne ciljeve inkubatora prikazane u Tablici 6., svi se ispitanici slažu da su poticanje gospodarskog razvoja, stvaranje uspješnih poduzeća te poticanje otvaranja radnih mjesta glavni ciljevi poduzetničkih inkubatora. Sudionici se također slažu ili se uglavnom slažu (76,4 \%) da poduzetnički inkubatori imaju za cilj pružanje potpore u transferu tehnologije, baš kao i da im je cilj povećanje broja stanara koji napuštaju inkubator. Od ostalih ciljeva, među kojima su pomoć sveučilištima u komercijalizaciji istraživanja, 44,1 \% inkubatora slaže se ili se uglavnom slaže da je to cilj prema kojemu su usmjereni. S druge strane, s ostvarivanjem profita kao osnovnog cilja prema kojem inkubatori trebaju biti usmjereni čak se 47 \% uopće ne slaže ili se uglavnom ne slaže, što ne začuđuje jer u uzorku prevladavaju neprofitni inkubatori čiji primarni cilj nije ostvarivanje profita. Prema Musterós Batlle (2016), ciljevi profitnih inkubatora više su usredotočeni na povrat ulaganja, dok neprofitni inkubatori za cilj imaju stvaranje radnih mjesta ili gospodarski razvoj.

Tablica 6. Glavni ciljevi inkubatora

\begin{tabular}{|c|c|c|c|c|c|c|}
\hline \multirow{2}{*}{$\begin{array}{l}\text { Glavni ciljevi } \\
\text { inkubatora }\end{array}$} & \multicolumn{6}{|c|}{ N (\%) } \\
\hline & $\begin{array}{l}\text { uopće } \\
\text { se ne } \\
\text { slažem }\end{array}$ & $\begin{array}{l}\text { uglavnom } \\
\text { se ne } \\
\text { slažem }\end{array}$ & $\begin{array}{c}\text { niti se } \\
\text { slažem niti } \\
\text { se ne slažem }\end{array}$ & $\begin{array}{l}\text { uglavnom } \\
\text { se slažem }\end{array}$ & $\begin{array}{l}\text { slažem } \\
\text { se }\end{array}$ & ukupno \\
\hline \multirow{2}{*}{$\begin{array}{l}\text { stvoriti uspješna } \\
\text { poduzeća }\end{array}$} & \multirow{2}{*}{0} & \multirow{2}{*}{0} & \multirow{2}{*}{0} & 8 & 26 & 34 \\
\hline & & & & $23,5 \%$ & $76,5 \%$ & $100 \%$ \\
\hline \multirow{2}{*}{$\begin{array}{l}\text { pomoć pri transferu } \\
\text { tehnologije }\end{array}$} & 1 & 3 & 4 & 8 & 18 & 34 \\
\hline & $2,9 \%$ & $8,8 \%$ & $11,8 \%$ & $23,5 \%$ & $52,9 \%$ & $100 \%$ \\
\hline \multirow{2}{*}{ ostvariti profit } & 4 & 12 & 7 & 8 & 3 & 34 \\
\hline & $11,8 \%$ & $35,3 \%$ & $20,6 \%$ & $23,5 \%$ & $8,8 \%$ & $100 \%$ \\
\hline \multirow{2}{*}{$\begin{array}{l}\text { pomoć sveučilištima } \\
\text { u komercijalizaciji } \\
\text { istraživanja }\end{array}$} & 1 & 8 & 10 & 6 & 9 & 34 \\
\hline & $2,9 \%$ & $23,5 \%$ & $29,4 \%$ & $17,6 \%$ & $26,5 \%$ & $100 \%$ \\
\hline \multirow{2}{*}{$\begin{array}{l}\text { otvaranje radnih } \\
\text { mjesta }\end{array}$} & \multirow{2}{*}{0} & \multirow[t]{2}{*}{0} & \multirow{2}{*}{0} & 10 & 24 & 34 \\
\hline & & & & $29,41 \%$ & $70,59 \%$ & $100 \%$ \\
\hline \multirow{2}{*}{$\begin{array}{l}\text { povećati broj } \\
\text { stanara koji } \\
\text { napuštaju inkubator }\end{array}$} & \multirow[b]{2}{*}{0} & 4 & 9 & 6 & 15 & 34 \\
\hline & & $11,76 \%$ & $26,47 \%$ & $17,65 \%$ & $44,12 \%$ & $100 \%$ \\
\hline \multirow{2}{*}{ gospodarski razvoj } & \multirow{2}{*}{0} & \multirow{2}{*}{0} & \multirow{2}{*}{0} & 6 & 28 & 34 \\
\hline & & & & $17,65 \%$ & $82,35 \%$ & $100 \%$ \\
\hline
\end{tabular}


Inkubatori obično postavljaju određene kriterije za ulazak poduzeća u inkubator te mogu imati određeni tržišni fokus koji se prema Musterós Batlle (2016) najčešće promatra u tri uvjeta: jesu li poduzeća poduzetnici početnici, jesu li određene veličine te pripadaju li određenom sektoru. Tablica 7. prikazuje da su promatrani inkubatori većinom usmjereni prema poduzetnicima početnicima, s čime se slaže ili se uglavnom slaže 79,4 \% inkubatora te da $32,4 \%$ inkubatora smatra da poduzeća moraju biti određene veličine. Manji broj $(32,4 \%)$ usmjeren je prema poduzećima iz određenog sektora, što ne iznenađuje jer prevladavaju višesektorski inkubatori.

Tablica 7. Tržišni fokus inkubatora

\begin{tabular}{|l|c|c|c|c|c|c|}
\hline \multicolumn{1}{|c|}{ Tržišni fokus } & \multicolumn{5}{|c|}{ N (\%) } \\
\hline & $\begin{array}{c}\text { uopće } \\
\text { se ne } \\
\text { slažem }\end{array}$ & $\begin{array}{c}\text { ug- } \\
\text { lavnom } \\
\text { se ne } \\
\text { slažem }\end{array}$ & $\begin{array}{c}\text { niti se } \\
\text { slažem niti } \\
\text { se ne slažem }\end{array}$ & $\begin{array}{c}\text { ug- } \\
\text { lavnom } \\
\text { se slažem }\end{array}$ & $\begin{array}{c}\text { slažem } \\
\text { se }\end{array}$ & ukupno \\
\hline $\begin{array}{l}\text { poduzeća moraju } \\
\text { biti poduzetnici } \\
\text { početnici }\end{array}$ & 3 & 2 & 2 & 11 & 16 & 34 \\
\cline { 2 - 7 } & $8,8 \%$ & $5,9 \%$ & $5,9 \%$ & $32,4 \%$ & $47,1 \%$ & $100 \%$ \\
\hline $\begin{array}{l}\text { poduzeća moraju } \\
\text { biti određene } \\
\text { veličine }\end{array}$ & 12 & 4 & 7 & 6 & 5 & 34 \\
\hline $\begin{array}{l}\text { poduzeća } \\
\text { moraju pripa- } \\
\text { dati određenomu } \\
\text { sektoru }\end{array}$ & $35,3 \%$ & $11,8 \%$ & $20,6 \%$ & $17,6 \%$ & $14,7 \%$ & $100 \%$ \\
\cline { 2 - 7 } & $32,4 \%$ & $8,8 \%$ & $26,5 \%$ & $20,6 \%$ & $11,8 \%$ & $100 \%$ \\
\hline
\end{tabular}

Izvor: autori.

Tablica 8. prikazuje kriterije selekcije pri ulasku poduzeća u inkubator, pri čemu su karakteristike poduzetnika najvažniji kriteriji selekcije, s čime se slaže $85,3 \%$ inkubatora. Zatim slijede poslovna ideja (88,2 \%), tržišni potencijal (73,5\%), dobro definirano tržište i klijenti $(67,6 \%)$, postojanje ili razvijanje novog proizvoda ili usluge (67,6 \%), sposobnost plaćanja najma ili usluga (64,7 $\%)$ te privlačnost za investitore $(58,8 \%)$. Stoga bi poduzetnici koji žele biti primljeni u inkubator trebali voditi računa o navedenim selekcijskim kriterijima. 
Tablica 8. Kriteriji selekcije

\begin{tabular}{|c|c|c|c|c|c|c|}
\hline \multirow[t]{2}{*}{ Kriteriji selekcije } & \multicolumn{6}{|c|}{ N (\%) } \\
\hline & $\begin{array}{l}\text { uopće } \\
\text { se ne } \\
\text { slažem }\end{array}$ & $\begin{array}{l}\text { uglavnom } \\
\text { se ne } \\
\text { slažem }\end{array}$ & $\begin{array}{c}\text { niti se } \\
\text { slažem niti } \\
\text { se ne slažem }\end{array}$ & $\begin{array}{l}\text { uglavnom } \\
\text { se slažem }\end{array}$ & $\begin{array}{c}\text { slažem } \\
\text { se }\end{array}$ & ukupno \\
\hline \multirow{2}{*}{$\begin{array}{l}\text { karakteristike } \\
\text { poduzetnika }\end{array}$} & \multirow{2}{*}{0} & 1 & 4 & 15 & 14 & 34 \\
\hline & & $2,9 \%$ & $11,8 \%$ & $44,1 \%$ & $41,2 \%$ & $100 \%$ \\
\hline \multirow{2}{*}{$\begin{array}{l}\text { dobro definirano } \\
\text { tržište i klijenti }\end{array}$} & \multirow{2}{*}{0} & 3 & 8 & 16 & 7 & 34 \\
\hline & & $8,8 \%$ & $23,5 \%$ & $47,1 \%$ & $20,6 \%$ & $100 \%$ \\
\hline \multirow[t]{2}{*}{ tržišni potencijal } & \multirow{2}{*}{0} & 4 & 5 & 16 & 9 & 34 \\
\hline & & $11,8 \%$ & $14,7 \%$ & $47,1 \%$ & $26,5 \%$ & $100 \%$ \\
\hline \multirow{2}{*}{$\begin{array}{l}\text { imati ili razvijati } \\
\text { nov proizvod ili } \\
\text { uslugu }\end{array}$} & 1 & 3 & 7 & 10 & 13 & 34 \\
\hline & $2,9 \%$ & $8,8 \%$ & $20,6 \%$ & $29,4 \%$ & $38,2 \%$ & $100 \%$ \\
\hline \multirow{2}{*}{$\begin{array}{l}\text { sposobnost } \\
\text { plaćanja najma i } \\
\text { usluga }\end{array}$} & 3 & 1 & 8 & 17 & 5 & 34 \\
\hline & $8,8 \%$ & $2,9 \%$ & $23,5 \%$ & $50 \%$ & $14,7 \%$ & $100 \%$ \\
\hline \multirow{2}{*}{$\begin{array}{l}\text { privlačnost za } \\
\text { investitore }\end{array}$} & 2 & 3 & 9 & 17 & 3 & 34 \\
\hline & $5,9 \%$ & $8,8 \%$ & $26,5 \%$ & $50 \%$ & $8,8 \%$ & $100 \%$ \\
\hline \multirow[t]{2}{*}{ poslovna ideja } & & 1 & 3 & 11 & 19 & 34 \\
\hline & & $2,9 \%$ & $8,8 \%$ & $32,4 \%$ & $55,9 \%$ & $100 \%$ \\
\hline
\end{tabular}

Izvor: autori.

U skladu s Musterós Batlle (2016), Tablica 9. prikazuje tri osnovna razloga zbog kojih poduzeća napuštaju inkubator, pri čemu najveći broj sudionika smatra da je potreba za dodatnim prostorom uzrokovana širenjem poslovanja osnovni razlog zbog kojeg poduzeća stanari izlaze iz inkubatora $(88,2$ \%). Na drugom su mjestu kriteriji za izlazak koje postavlja inkubator $(44,1$ \%), dok svega $38,2 \%$ smatra da je razlog neuspjeh poduzeća (Tablica 9.).

Tablica 9. Razlozi za napuštanje inkubatora

\begin{tabular}{|l|c|c|c|c|c|c|}
\hline $\begin{array}{c}\text { Razlozi za napu- } \\
\text { štanje inkubatora }\end{array}$ & \multicolumn{7}{|c|}{ N (\%) } \\
\hline & $\begin{array}{c}\text { uopće } \\
\text { se ne } \\
\text { slažem }\end{array}$ & $\begin{array}{c}\text { uglavnom } \\
\text { se ne } \\
\text { slažem }\end{array}$ & $\begin{array}{c}\text { niti se } \\
\text { slažem niti } \\
\text { se ne slažem }\end{array}$ & $\begin{array}{c}\text { uglavnom } \\
\text { se slažem }\end{array}$ & $\begin{array}{c}\text { slažem } \\
\text { se }\end{array}$ & ukupno \\
\hline $\begin{array}{l}\text { zbog kriterija za } \\
\text { izlazak }\end{array}$ & 10 & 2 & 7 & 8 & 7 & 34 \\
\cline { 2 - 8 } & $29,4 \%$ & $5,9 \%$ & $20,6 \%$ & $23,5 \%$ & $20,6 \%$ & $100 \%$ \\
\hline
\end{tabular}




\begin{tabular}{|l|c|c|c|c|c|c|}
\hline $\begin{array}{l}\text { zbog prostora za } \\
\text { širenje }\end{array}$ & 0 & 1 & 3 & 11 & 19 & 34 \\
\cline { 2 - 7 } & $2,9 \%$ & $8,8 \%$ & $32,4 \%$ & $55,9 \%$ & $100 \%$ \\
\hline $\begin{array}{l}\text { zbog neuspjeha } \\
\text { poduzeća }\end{array}$ & 6 & 9 & 6 & 11 & 2 & 34 \\
\cline { 2 - 7 } & $17,6 \%$ & $26,5 \%$ & $17,6 \%$ & $32,4 \%$ & $5,9 \%$ & $100 \%$ \\
\hline
\end{tabular}

Izvor: autori.

CSES (2002) navodi da poduzetnički inkubatori imaju veće izglede za uspjeh ako imaju potporu javnih i privatnih sponzora, pri čemu je u početnim fazama osnivanja i poslovanja inkubatora ključno osigurati financiranje iz javnih poticajnih sredstva. Sudionici istraživanja u najvećoj se mjeri slažu da su najvažniji sponzori inkubatora država i EU (67,6 \%) te javni subjekti / JLPRS (55,9 \%). Uloga banaka, fondova rizičnog kapitala, sveučilišta i privatnih poduzeća u financiranju inkubatora nije posebno istaknuta (Tablica 10.). Iz Tablice je također vidljivo da se iznimno malen broj inkubatora oslanja na sponzorstvo privatnih poduzeća $(\mathrm{N}=6,17,6$ \%). Dakle, može se zaključiti da prevladavaju neprofitni inkubatori koje osnivaju javni osnivači, uglavnom tijela lokalne i područne (regionalne) samouprave, pri čemu u svojim proračunima ujedno osiguravaju i potpore za poslovanje inkubatora.

\section{Tablica 10. Sponzori inkubatora}

\begin{tabular}{|c|c|c|c|c|c|c|}
\hline \multirow[t]{2}{*}{ Sponzori } & \multicolumn{6}{|c|}{ N (\%) } \\
\hline & $\begin{array}{l}\text { uopće } \\
\text { se ne } \\
\text { slažem }\end{array}$ & $\begin{array}{l}\text { uglavnom } \\
\text { se ne } \\
\text { slažem }\end{array}$ & $\begin{array}{c}\text { niti se } \\
\text { slažem niti } \\
\text { se ne slažem }\end{array}$ & $\begin{array}{l}\text { uglavnom } \\
\text { se slažem }\end{array}$ & $\begin{array}{l}\text { slažem } \\
\text { se }\end{array}$ & ukupno \\
\hline \multirow{2}{*}{$\begin{array}{l}\text { sveučilište/ } \\
\text { veleučilište }\end{array}$} & 22 & 5 & 2 & 2 & 3 & 34 \\
\hline & $64,7 \%$ & $14,7 \%$ & $5,9 \%$ & $5,9 \%$ & $8,8 \%$ & $100 \%$ \\
\hline \multirow[t]{2}{*}{ privatno poduzeće } & 24 & 2 & 2 & 3 & 3 & 34 \\
\hline & $70,6 \%$ & $5,9 \%$ & $5,9 \%$ & $8,8 \%$ & $8,8 \%$ & $100 \%$ \\
\hline \multirow{2}{*}{$\begin{array}{l}\text { javni subjekti / } \\
\text { JLPRS }\end{array}$} & 6 & 6 & 3 & 4 & 15 & 34 \\
\hline & $17,6 \%$ & $17,6 \%$ & $8,8 \%$ & $11,8 \%$ & $44,1 \%$ & $100 \%$ \\
\hline \multirow[t]{2}{*}{ država i EU } & 4 & 3 & 4 & 11 & 12 & 34 \\
\hline & $11,8 \%$ & $8,8 \%$ & $11,8 \%$ & $32,4 \%$ & $35,3 \%$ & $100 \%$ \\
\hline \multirow{2}{*}{$\begin{array}{l}\text { fondovi rizičnog } \\
\text { kapitala }\end{array}$} & 26 & 3 & 3 & 2 & \multirow{2}{*}{0} & 34 \\
\hline & $76,5 \%$ & $8,8 \%$ & $8,8 \%$ & $5,9 \%$ & & $100 \%$ \\
\hline \multirow[t]{2}{*}{ banke } & 29 & 2 & \multirow{2}{*}{0} & 2 & 1 & 34 \\
\hline & $85,3 \%$ & $5,9 \%$ & & $5,9 \%$ & $2,9 \%$ & $100 \%$ \\
\hline
\end{tabular}

Izvor: autori. 


\subsection{Analiza usluga koje pružaju inkubatori}

Istraživanjem se nastojalo utvrditi koje sve usluge inkubatori pružaju poduzećima stanarima, pri čemu su postavljena pitanja o dostupnosti pojedinih usluga podijeljenih u pet osnovnih kategorija: infrastrukturne usluge, financijske usluge, usluge umrežavanja, pravne usluge i usluge upravljanja ljudskim resursima te usluge poslovnog savjetovanja. Navedenih pet osnovnih kategorija dalje je podijeljeno na više potkategorija koje je moguće vidjeti u Tablici 11. Od infrastrukturnih usluga u svim je inkubatorima osiguran pristup internetu, IT oprema i namještaj te su dostupne sobe za sastanke. Također, gotovo svi inkubatori (94,1 \%) imaju čajnu kuhinju ili kantinu te nude uslugu zakupa poslovnog prostora (91,2 \%). U više od 50 \% slučajeva također su dostupni tehnološki prostori poput laboratorija ili slično.

Pružanje financijskih usluga manje je razvijeno, pri čemu je najčešća usluga koju inkubatori pružaju pomoć u izradi procjene poduzeća, 64,7 \% inkubatora nudi navedenu uslugu. Manje od polovine inkubatora omogućuje pristup fondovima rizičnog kapitala (41,2 \%) te samo 38,2 \% pruža pristup kapitalu poslovnih anđela. Također, tek nekolicina poduzetničkih inkubatora (14,7 \%) osigurava početni kapital ili zajmove poduzećima, dok je financiranje autorskih prava dostupno u svega dva inkubatora.

U gotovo svim inkubatorima dostupne su usluge umrežavanja, pri čemu su podjednako razvijene aktivnosti internog umrežavanja (unutar inkubatora) kao i aktivnosti vanjskog umrežavanja (izvan inkubatora). Od pravnih usluga i usluga u upravljanju ljudskim resursima najčešće je dostupna pomoć pri zapošljavanju koju pruža 70,6 \% inkubatora i pomoć u ishođenju dozvola koju osigurava 67,6 \% inkubatora. U više od polovice inkubatora dostupna je usluga pomoći pri zaštiti intelektualnog vlasništva $(55,9$ \%) te pomoći u zaštiti autorskih prava i patenata (50,0 \%), dok pomoć u oporezivanju pruža 44,1\% inkubatora.

Iz analiziranih rezultata vidljivo je da su razvijene i usluge poslovnog savjetovanja, pri čemu svi inkubatori omogućuju stanarima sudjelovanje na radionicama, a 88,2 \% pruža potporu u izradi poslovnog i marketinškog plana, omogućuje poslovno obučavanje te pomaže u sudjelovanju na konferencijama i sajmovima. U 82,4 \% slučajeva dostupna je pomoć u istraživanju i razvoju, 79,4 \% u oglašavanju i brendiranju, u 67,6 \% omogućava se pristup bazama podataka te u 82,4 \% pomoć u prodajnim i marketinškim uslugama. 
Tablica 11. Dostupnost usluga

\begin{tabular}{|c|c|c|c|c|c|c|}
\hline \multirow[t]{2}{*}{ Usluge } & \multicolumn{6}{|c|}{ N (\%) } \\
\hline & \multicolumn{2}{|c|}{ dostupno } & \multicolumn{2}{|c|}{ nije dostupno } & \multicolumn{2}{|c|}{ ukupno } \\
\hline \multicolumn{7}{|l|}{ Infrastrukturne usluge } \\
\hline pristup internetu & 34 & $100 \%$ & \multicolumn{2}{|c|}{0} & 34 & $100 \%$ \\
\hline usluge čajne kuhinje ili kantine & 32 & $94,1 \%$ & 2 & $5,9 \%$ & 34 & $100 \%$ \\
\hline sobe za sastanke & 34 & $100 \%$ & \multicolumn{2}{|r|}{0} & 34 & $100 \%$ \\
\hline IT oprema i namještaj & 34 & $100 \%$ & \multicolumn{2}{|c|}{0} & 34 & $100 \%$ \\
\hline usluge tajništva ili recepcije & 18 & $52,9 \%$ & 16 & $47,1 \%$ & 34 & $100 \%$ \\
\hline zakup poslovnog prostora & 31 & $91,2 \%$ & 3 & $8,8 \%$ & 34 & $100 \%$ \\
\hline tehnološki prostori (laboratoriji i sl.) & 19 & $55,9 \%$ & 15 & $44,1 \%$ & 34 & $100 \%$ \\
\hline \multicolumn{7}{|l|}{ Financijske usluge } \\
\hline pristup fondovima rizičnog kapitala & 14 & $41,2 \%$ & 20 & $58,8 \%$ & 34 & $100 \%$ \\
\hline pružanje zajmova & 5 & $14,7 \%$ & 29 & $85,3 \%$ & 34 & $100 \%$ \\
\hline pružanje početnog kapitala & 5 & $14,7 \%$ & 29 & $85,3 \%$ & 34 & $100 \%$ \\
\hline pristup kapitalu poslovnih anđela & 13 & $38,2 \%$ & 21 & $61,8 \%$ & 34 & $100 \%$ \\
\hline financiranje autorskih prava & 2 & $5,9 \%$ & 32 & $94,1 \%$ & 34 & $100 \%$ \\
\hline pomoć u izradi procjene poduzeća & 22 & $64,7 \%$ & 12 & $35,3 \%$ & 34 & $100 \%$ \\
\hline \multicolumn{7}{|l|}{ Usluge umrežavanja } \\
\hline $\begin{array}{l}\text { povezivanje s drugim poduzećima } \\
\text { stanarima }\end{array}$ & 34 & $100 \%$ & \multicolumn{2}{|c|}{0} & 34 & $100 \%$ \\
\hline $\begin{array}{l}\text { povezivanje s poslovnim } \\
\text { stručnjacima }\end{array}$ & 34 & $100 \%$ & \multicolumn{2}{|c|}{0} & 34 & $100 \%$ \\
\hline $\begin{array}{l}\text { povezivanje sa zaposlenicima } \\
\text { inkubatora }\end{array}$ & 34 & $100 \%$ & \multicolumn{2}{|c|}{0} & 34 & $100 \%$ \\
\hline povezivanje sa sveučilištima & 33 & $97,1 \%$ & 1 & $2,9 \%$ & 34 & $100 \%$ \\
\hline povezivanje s financijskim akterima & 33 & $97,1 \%$ & 1 & $2,9 \%$ & 34 & $100 \%$ \\
\hline $\begin{array}{l}\text { povezivanje s kontaktima iz indus- } \\
\text { trije }\end{array}$ & 33 & $97,1 \%$ & 1 & $2,9 \%$ & 34 & $100 \%$ \\
\hline \multicolumn{7}{|c|}{ Pravne usluge i usluge upravljanja ljudskim resursima } \\
\hline $\begin{array}{l}\text { pomoć pri zaštiti intelektualnog } \\
\text { vlasništva }\end{array}$ & 19 & $55,9 \%$ & 15 & $44,1 \%$ & 34 & $100 \%$ \\
\hline pomoć u oporezivanju & 15 & $44,1 \%$ & 19 & $55,9 \%$ & 34 & $100 \%$ \\
\hline $\begin{array}{l}\text { pomoć pri zaštiti autorskih prava i } \\
\text { patenata }\end{array}$ & 17 & $50,0 \%$ & 17 & $50,0 \%$ & 34 & $100 \%$ \\
\hline pomoć u ishođenju dozvola & 23 & $67,6 \%$ & 11 & $32,4 \%$ & 34 & $100 \%$ \\
\hline pomoć pri zapošljavanju & 24 & $70,6 \%$ & 10 & $29,4 \%$ & 34 & $100 \%$ \\
\hline \multicolumn{7}{|l|}{ Usluge poslovnog savjetovanja } \\
\hline pomoć u izradi marketinškog plan & 30 & $88,2 \%$ & 4 & $11,8 \%$ & 34 & $100 \%$ \\
\hline
\end{tabular}




\begin{tabular}{|l|c|c|c|c|c|c|}
\hline pristup bazama podataka & 23 & $67,6 \%$ & 11 & $32,4 \%$ & 34 & $100 \%$ \\
\hline oglašavanje i brendiranje & 27 & $79,4 \%$ & 7 & $20,6 \%$ & 34 & $100 \%$ \\
\hline poslovno obučavanje & 30 & $88,2 \%$ & 4 & $11,8 \%$ & 34 & $100 \%$ \\
\hline $\begin{array}{l}\text { obučavanje i treninzi u razvoju } \\
\text { poslovnog plana }\end{array}$ & 30 & $88,2 \%$ & 4 & $11,8 \%$ & 34 & $100 \%$ \\
\hline radionice & 34 & $100 \%$ & \multicolumn{2}{|c|}{0} & 34 & $100 \%$ \\
\hline $\begin{array}{l}\text { pomoć u sudjelovanju na konferen- } \\
\text { cijama i sajmovima }\end{array}$ & 30 & $88,2 \%$ & 4 & $11,8 \%$ & 34 & $100 \%$ \\
\hline prodajne i marketinške usluge & 20 & $58,8 \%$ & 14 & $41,2 \%$ & 34 & $100 \%$ \\
\hline pomoć u istraživanju i razvoju & 28 & $82,4 \%$ & 6 & $17,6 \%$ & 34 & $100 \%$ \\
\hline
\end{tabular}

Izvor: autori.

Uz prethodno navedene inkubacijske usluge, u 82,4 \% slučajeva inkubatori pružaju i usluge predinkubacije baš kao i usluge postinkubacije u 70,6 $\%$ slučajeva (Tablica 12.). Usluge predinkubacije namijenjene su poduzetnicima koji su u fazi osnivanja poduzeća i za cilj imaju pružanje pomoći u izradi poslovnoga plana. S druge strane, usluge postinkubacije omogućuju poduzećima koja su spremna za samostalno poslovanje da se i dalje koriste određenim uslugama koje inkubator pruža.

Tablica 12. Predinkubacijske i postinkubacijske usluge

\begin{tabular}{|l|l|c|}
\hline & N & $\%$ \\
\hline predinkubacijske usluge & 28 & $82,4 \%$ \\
\hline postinkubacijske usluge & 24 & $70,6 \%$ \\
\hline
\end{tabular}

Izvor: autori.

Zanimljivo je također promotriti stavove ispitanika (Tablica 13.) o važnosti pojedine skupine usluga koje nude inkubatori, pri čemu $50 \%$ inkubatora smatra da su infrastrukturne usluge najvažnije, zatim slijede usluge poslovnog savjetovanja $(26,5 \%)$ te usluge umrežavanja $(23,5 \%)$.

Tablica 13. Važnost usluga inkubatora

\begin{tabular}{|l|c|c|}
\hline & N & $\%$ \\
\hline infrastrukturne usluge & 17 & $50 \%$ \\
\hline usluge poslovnog savjetovanja & 9 & $26,5 \%$ \\
\hline usluge umrežavanja & 8 & $23,5 \%$ \\
\hline ukupno & 34 & $100 \%$ \\
\hline
\end{tabular}

Izvor: autori. 


\subsection{Analiza uspješnosti inkubatora}

Ovim istraživanjem uspješnost inkubatora mjeri se s pomoću tri različite skupine pitanja: uspjehom inkubatora, uspjehom inkubatora u pružanju usluga te samoodrživosti inkubatora (CSES, 2002; Tang et al., 2014; Musterós Batlle, 2016; OECD, 2019). Kada se promatra samoodrživost inkubatora, ispitanici navode da su inkubatori samoodrživi u 58,8 \% slučajeva, dok u 41,2 \% slučajeva smatraju da inkubatori nisu samoodrživi (Tablica 14.).

Tablica 14. Samoodrživost inkubatora

\begin{tabular}{|l|c|c|}
\hline \multicolumn{1}{|c|}{ Inkubator je samoodrživ } & \multicolumn{2}{|c|}{ N (\%) } \\
\hline da & 20 & $58,8 \%$ \\
\hline ne & 14 & $41,2 \%$ \\
\hline ukupno & 34 & $100 \%$ \\
\hline
\end{tabular}

Izvor: autori.

Većina sudionika istraživanja smatra da je inkubator uspješan, s čime se slaže 94,1 \% ispitanika (Tablica 15.). Uspjeh inkubatora moguće je promatrati i na način kako inkubatori organiziraju i upravljaju procesima inkubacije, pri čemu je moguće uzeti u obzir različite elemente kao što su kriteriji selekcije poduzeća stanara, usluge poslovne potpore te usluge umrežavanja (Bergek \& Norrman, 2008).

Tablica 15. Uspjeb inkubatora

\begin{tabular}{|l|c|c|c|c|c|c|}
\hline & \multicolumn{7}{|c|}{ N (\%) } \\
\hline & $\begin{array}{c}\text { uopće } \\
\text { se ne } \\
\text { slažem }\end{array}$ & $\begin{array}{c}\text { uglavnom } \\
\text { se ne } \\
\text { slažem }\end{array}$ & $\begin{array}{c}\text { niti se } \\
\text { slažem niti } \\
\text { se ne slažem }\end{array}$ & $\begin{array}{c}\text { uglavnom } \\
\text { se slažem }\end{array}$ & $\begin{array}{c}\text { slažem } \\
\text { se }\end{array}$ & ukupno \\
\hline $\begin{array}{l}\text { inkubator je } \\
\text { uspješan }\end{array}$ & 0 & 1 & 1 & 19 & 13 & 34 \\
\cline { 3 - 8 } & $2,9 \%$ & $2,9 \%$ & $55,9 \%$ & $38,2 \%$ & $100 \%$ \\
\hline
\end{tabular}

Izvor: autori.

U nastojanju jasnijeg razumijevanja uspješnosti inkubatora Tablica 16. pruža detaljniju analizu uspješnosti inkubatora u pružanju pojedinih skupina usluga. Iz Tablice 16. vidljivo je da su inkubatori najuspješniji u pru- 
žanju usluga umrežavanja, s čime se slažu svi sudionici kao i u pružanju infrastrukturnih usluga i usluga povezivanja s potencijalnim investitorima $(97,1 \%)$. Gotovo polovica ispitanika slaže se da su inkubatori uspješni u pružanju pravnih usluga i usluga upravljanja ljudskim resursima. Inkubatori su najmanje uspješni u pružanju financijskih usluga, gdje svega 35,3 \% ispitanika smatra da je inkubator uspješan u tome području.

\section{Tablica 16. Uspjeb inkubatora u pružanju usluga}

\begin{tabular}{|c|c|c|c|c|c|c|}
\hline \multirow{2}{*}{$\begin{array}{l}\text { Uspjeh inkuba- } \\
\text { tora u pružanju } \\
\text { usluga }\end{array}$} & \multicolumn{6}{|c|}{ N (\%) } \\
\hline & $\begin{array}{l}\text { uopće } \\
\text { se ne } \\
\text { slažem }\end{array}$ & $\begin{array}{l}\text { uglavnom } \\
\text { se ne } \\
\text { slažem }\end{array}$ & $\begin{array}{c}\text { niti se } \\
\text { slažem niti } \\
\text { se ne slažem }\end{array}$ & $\begin{array}{l}\text { uglavnom } \\
\text { se slažem }\end{array}$ & $\begin{array}{l}\text { slažem } \\
\text { se }\end{array}$ & ukupno \\
\hline \multirow{2}{*}{$\begin{array}{l}\text { infrastrukturne } \\
\text { usluge }\end{array}$} & \multirow{2}{*}{0} & \multirow{2}{*}{0} & 1 & 3 & 30 & 34 \\
\hline & & & $2,9 \%$ & $8,8 \%$ & $88,2 \%$ & $100 \%$ \\
\hline \multirow{2}{*}{ pravne usluge } & \multirow{2}{*}{$\begin{array}{c}4 \\
11,8 \% \\
\end{array}$} & 5 & 7 & 6 & 12 & 34 \\
\hline & & $14,7 \%$ & $20,6 \%$ & $17,6 \%$ & $35,3 \%$ & $100 \%$ \\
\hline \multirow{2}{*}{$\begin{array}{l}\text { usluge u uprav- } \\
\text { ljanju ljudskim } \\
\text { resursima }\end{array}$} & \multirow{2}{*}{$\begin{array}{c}4 \\
11,8 \%\end{array}$} & 3 & 11 & 9 & 7 & 34 \\
\hline & & $8,8 \%$ & $32,4 \%$ & $26,5 \%$ & $20,6 \%$ & $100 \%$ \\
\hline \multirow{2}{*}{$\begin{array}{l}\text { usluge } \\
\text { umrežavanja }\end{array}$} & \multirow{2}{*}{0} & \multirow{2}{*}{0} & \multirow{2}{*}{0} & 7 & 27 & 34 \\
\hline & & & & $20,6 \%$ & $79,4 \%$ & $100 \%$ \\
\hline \multirow{2}{*}{$\begin{array}{l}\text { povezivanje s } \\
\text { potencijalnim } \\
\text { investitorima }\end{array}$} & \multirow[b]{2}{*}{0} & \multirow{2}{*}{0} & 1 & 18 & 15 & 34 \\
\hline & & & $2,9 \%$ & $52,9 \%$ & $44,1 \%$ & $100 \%$ \\
\hline \multirow{2}{*}{ financijske usluge } & 5 & 4 & 13 & 7 & 5 & 34 \\
\hline & $14,7 \%$ & $11,8 \%$ & $38,2 \%$ & $20,6 \%$ & $14,7 \%$ & $100 \%$ \\
\hline \multirow{2}{*}{$\begin{array}{l}\text { usluge poslovnog } \\
\text { savjetovanja }\end{array}$} & 1 & \multirow{2}{*}{0} & 2 & 6 & 25 & 34 \\
\hline & $2,9 \%$ & & $5,9 \%$ & $17,6 \%$ & $73,5 \%$ & $100 \%$ \\
\hline
\end{tabular}

Izvor: autori.

\section{Diskusija}

Poduzetnički inkubatori imaju važnu ulogu u pružanju potpore malim i srednjim poduzećima na lokalnoj i na regionalnoj razini. Posebice se navedeno odnosi na pružanje potpore poduzetnicima početnicima koji su ujedno i ciljna skupina poduzetničkih inkubatora. Smještaj u poduzetnič- 
kome inkubatoru poboljšava njihove izglede za opstanak na tržištu. Ovo istraživanje pokazalo je da najveći broj inkubatora (gotovo 80 \%) stavlja fokus upravo na poduzetnike početnike. Međutim, sam smještaj u inkubatoru ne jamči ujedno i uspjeh poduzeća (OECD, 2019), što je vidljivo iz rezultata istraživanja gdje gotovo $40 \%$ inkubatora navodi da poduzeća napuštaju inkubator zbog poslovnog neuspjeha.

Inkubatori u RH svojim stanarima pružaju uobičajene usluge kao što su subvencioniran najam poslovnog prostora, savjetodavne usluge i edukacije te usluge povezivanja s financijskim akterima (Bošnjak, 2011). Prema rezultatima istraživanja, vidljivo je da većina poduzetničkih inkubatora smatra da su infrastrukturne usluge najvažnije te da je pružanje usluge poslovnog ili radnog prostora osnovno obilježje inkubatora. Pružanje usluga zakupa poslovnog prostora, poslovnog savjetovanja i usluga umrežavanja u pravilu je dobro razvijeno i omogućuje poduzećima stanarima znatno lakšu startnu poziciju u postizanju uspjeha njihova poduzetničkog pothvata. Određene su usluge manje zastupljene, a odnose se prije svega na financijske usluge gdje tek nekolicina inkubatora osigurava poduzećima stanarima mogućnosti financiranja.

S obzirom na to da je osnovni cilj inkubatora omogućiti uspjeh poduzeća te osigurati stalan protok poduzeća kroz inkubator, može se zaključiti da je upravo ograničavanje vremena boravka poduzeća u inkubatoru nužno da bi se stanare potaknulo na samostalno poslovanje te da bi se ujedno oslobodio prostor unutar inkubatora za primitak novih stanara. U skladu s Musterós Batlle (2016), istraživanje je utvrdilo da su potreba za dodatnim prostorom uzrokovana širenjem poslovanja, kriteriji za izlazak koje postavlja inkubator te neuspjeh poduzeća osnovni razlozi zbog kojih poduzeća napuštaju inkubator

Cijeli sustav poduzetničkih potpornih institucija u RH čini se dobro razvijen i ravnomjerno regionalno rasprostranjen, pri čemu je u potpornim institucijama zaposlen adekvatan broj zaposlenika. Također, uspostavljen je Jedinstveni registar poduzetničke infrastrukture gdje su evidentirani subjekti poduzetničke infrastrukture. Poduzetničke potporne institucije u pravilu imaju dobru potporu jedinica lokalne i područne (regionalne) samouprave te potporu države, međutim trebale bi se usmjeriti prema ostvarivanju veće financijske samoodrživosti, podizanju kvalitete usluga te rješavanju zapreka daljnjeg poticanja razvoja poduzetništva u svojim sredinama. Preporuke koje je korisno spomenuti jesu: proširenje postojećih kapaciteta inkubatora, bolje povezivanje i umrežavanje između različitih potpornih institucija radi pružanja šire potpore razvoju poduzetništva u svojim sredinama te stavljanja naglaska na kontinuirano usavršavanje zaposlenika inkubatora. 
Budući da su selekcija ili odabir poduzeća stanara važan zadatak voditelja inkubatora (Peters, Rice \& Sundararajan, 2004; OECD, 2019), voditelji inkubatora trebali bi posjedovati određena tehnološka znanja da bi mogli procijeniti potencijal i održivost poduzetnikove poslovne ideje. Također, osim općenitih zakonitosti razvoja poslovanja, trebali bi biti u stanju procijeniti poduzetnikovu osobnost, iskustvo i vještine (Bergek \& Norrman, 2008). S obzirom na to da su u istraživanju uglavnom sudjelovali voditelji inkubatora koji su višeg i visokog obrazovanja, može se zaključiti da postoji prostor za dodatne specijalizirane obrazovne programe usmjerene na voditelje inkubatora s obzirom na njihovu ulogu u uspješnom poslovanju inkubatora.

\subsection{Teorijske i praktične implikacije istraživanja}

Ovo istraživanje doprinosi boljem razumijevanju uloge i značenja koje poduzetnički inkubatori imaju u pokretanju novoga poduzetničkog pothvata. Nadalje, rad doprinosi konceptualnom razumijevanju svih najvažnijih odrednica poslovanja poduzetničkih inkubatora, pri čemu donositelji odluka javnih politika te voditelji poduzetničkih inkubatora mogu bolje razumjeti kako pomoći u privlačenju potrebnih izvora financiranja te razvoja novih perspektivnih poduzeća. Stoga rezultati ovog istraživanja mogu biti od znatne koristi državnim/javnim institucijama i nevladinim/neprofitnim institucijama u izradi javnih politika namijenjenih povećanju kvalitete te održivosti poduzetništva. U praktičnome smislu rezultati ovog istraživanja mogu poslužiti voditeljima inkubatora, široj javnoj upravi te široj poslovnoj zajednici (posebice start-up zajednici) jer je pružen pregled osnovnih usluga koje inkubatori nude svojim poduzećima stanarima. Također, s obzirom na to da rad pruža jasniju sliku trenutačnog stanja razvijenosti i uspješnosti poduzetničkih inkubatora, rezultati istraživanja mogu poslužiti inovatorima i poduzetnicima početnicima koji se dvoume u vezi s korištenjem infrastrukturom i uslugama poduzetničkih inkubatora. Zaključno, rad može poslužiti raznim donositeljima odluka u izradi programa namijenjenih jačanju institucijske i regulacijske potpore poduzetništva.

\subsection{Ograničenja istraživanja}

U ovom dijelu rada nužno je istaknuti da istraživački dio rada svakako pati od određenih ograničenja. Jedno od osnovnih ograničenja istraživanja odnosi se na subjektivnu procjenu ispitanika, posebice u dijelu koji se odnosio na analizu uspješnosti inkubatora, stoga bi bilo korisno u budu- 
ćim istraživanjima koristiti se sekundarnim kvantitativnim pokazateljima uspješnosti. Također, u istraživanju su sudjelovali isključivo predstavnici poduzetničkih inkubatora, zbog čega bi svakako bilo korisno istražiti i percepciju poduzeća stanara koja se koriste uslugama inkubatora u vezi s kvalitetom usluga koje inkubatori pružaju i s njihovom percepcijom uspješnosti inkubatora. Nadalje, veličina uzorka također je određen nedostatak jer je istraživanje ispitalo stavove predstavnika samo 34 inkubatora te bi buduća istraživanja trebala nastojati obuhvatiti veći broj ispitanika unutar pojedinog inkubatora i veći broj samih inkubatora. Usto, budući da je istraživanje provedeno od ožujka do travnja 2021. godine, čime je pružen presjek u promatranom vremenu, buduća istraživanja trebala bi se fokusirati na duže razdoblje unutar kojeg bi se promatralo poslovanje i uspješnost poduzetničkih inkubatora.

\section{Zaključak}

Kako je već navedeno, poduzetnički inkubatori u Republici Hrvatskoj relativno su noviji fenomen te je moguće da se i iz tog razloga više oslanjaju na javna sredstva i potpore nego na privatne izvore financiranja. Istraživanje je pokazalo da većina ispitanika smatra da su država i EU kao i jedinice lokalne i područne (regionalne) samouprave najvažniji sponzori inkubatora kao i da je stupanj samoodrživosti inkubatora nedovoljno visok, što znači da postoji potreba za znatnim sufinanciranjem inkubatora od osnivača i države. Osim privatnih izvora financiranja, jedan su od načina na koje je moguće povećati samoodrživost inkubatora i prihodi od poduzeća stanara, bilo prihodima od naknada za najam prostora ili prihodima od naplaćivanja usluga. Ovim istraživanjem nije analizirana struktura prihoda poduzetničkih inkubatora, stoga bi bilo zanimljivo promotriti ostvaruju li inkubatori prihode od svojih poduzeća stanara i, ako da, u kojem postotku. Stoga, kao što je već spomenuto, radi povećanja samoodrživosti potrebno je uključiti privatne sponzore poput privatnih poduzeća i banaka, što bi u konačnici trebalo pozitivno utjecati na poslovnu uspješnost inkubatora, a samim time i njihovih stanara.

\section{Literatura}

Bergek, A., \& Norrman, C. (2008). Incubator best practice: A framework. Technovation, 28(1-2), 20-28, https://doi.org/10.1016/j.technovation.2007.07.008 
Bošnjak, S. (2011). Poslovni inkubatori kao generatori razvoja poduzetništva. Praktični menadžment: stručni časopis za teoriju i praksu menadžmenta, 2(2), 51-56.

CSES - Centre for Strategy \& Evaluation Services. (2002). Benchmarking of business incubators.

Čizmadija, I., \& Stanković, D. (2011). Poduzetnički inkubatori u edukaciji za poduzetništvo. Učenje za poduzetništvo, 1(1), 129-139.

Dragičević, M., \& Obadić, A. (2006). Regionalni klasteri i novo zapošljavanje u Hrvatskoj. Zagreb, Hrvatska: Ekonomski fakultet.

Dutt, N., Hawn, O., Vidal, E., Chatterji, A., McGahan, A., \& Mitchell, W. (2016). How open system intermediaries address institutional failures: The case of business incubators in emerging-market countries. Academy of Management Journal, 59(3), 818-840, https://doi.org/10.5465/amj.2012.0463

Hackett, S. M., \& Dilts, D. M. (2004). A systematic review of business incubation research. The Journal of Technology Transfer, 29(1), 55-82.

Li, C., Ahmed, N., Qalati, S. A., Khan, A., \& Naz, S. (2020). Role of business incubators as a tool for entrepreneurship development: the mediating and moderating role of business start-up and government regulations. Sustainability, 12(5), 1822, https://doi.org/10.3390/su12051822

Matić, L. (23. 9. 2019.). Uloga poduzetničkih potpornih institucija u razvoju poduzetništva u Republici Hrvatskoj [diplomski rad]. Sveučilište u Zagrebu, Ekonomski fakultet.

Medić, I. (2004). Institucionalna potpora Start-up poduzetničkim pothvatima na području grada Osijeka - slučaj poduzetnički inkubator Osijek. Osijek, Hrvatska: Sveučilište Josipa Strossmayera, Ekonomski fakultet, https://doi. org/10.24869/psihei.2020.276

Musterós Batlle. S. (2016). Performance of Business Incubators: The Stakeholders Perspective. Dostupno na https://www.semanticscholar.org/paper/Performance-of-Business-incubators-\%3A-the-Muster\%C3\%B3s/e5096566e4d3 2bc48fd1ac5cc69a5d9cbebeb5e0

OECD (1997) Technology incubators: Nurturing small firms. Pariz, Francuska: OECD Publishing.

OECD (2019). Policy brief on incubators and accelerators that support inclusive entrepreneurship. Luxembourg, Luksemburg: Publications Office of the European Union, https://doi.org/10.1787/d7d81c23-en

Pace, G. (2001). The role of development agencies for the entrepreneurial promotion: Israeli case studies. Dostupno na https://www.academia.edu/1221458/ The_role_of_development_agencies_for_the_entrepreneurial_promotion_ Israeli_case_studies

Peters, L., Rice, M., \& Sundararajan, M. (2004). The role of incubators in the entrepreneurial process. The Journal of Technology Transfer, 29(1), 83-91, https:// doi.org/10.1023/b:jott.0000011182.82350.df

Shalaby, N. (2007). Enhancing incubator performance towards sustainability. Economic Focus, 2(2), 48-53. 
Strategija razvoja poduzetništva u Republici Hrvatskoj za razdoblje od 2013. do 2020. godine (2013). Dostupno na https://vlada.gov.hr/UserDocsImages// ZPPI/Strategije\%20-\%20OGP/poduzetni\%C5\%A1tvo//Strategija\%20razvoja\%20poduzetni\%C5\%A1tval.pdf

Tang, M. F., Lee, J., Liu, K., Lu, Y. (2014). Assessing government-supported technology-based business incubators: evidence from China. International Journal of Technology Management, 65(1-4), 24-48.

Tupek, K. L., \& Ćorić, G. (2018). Utjecaj poduzetničkih inkubatora na generiranje ideja i uspjeh start-up projekata u Hrvatskoj. Obrazovanje za poduzetništvoE4E: znanstveno stručni časopis o obrazovanju za poduzetništvo, 8(1), 125-152, https://doi.org/10.38190/ope.10.1.9

Zekić, Z., \& Bukovac, B. (2008). Tehnološki parkovi-agensi poduzetničkoga razvoja hrvatskoga gospodarstva. Ekonomska misao i praksa, 1, 105-116.

\section{Propisi}

Zakon o unapređenju poduzetničke infrastrukture, NN 93/13, 114/13, 41/14, $57 / 18$

\section{BUSINESS INCUBATORS AS A FORM OF ENTREPRENEURIAL SUPPORT IN CROATIA}

\section{Summary}

Business incubators represent one of the forms of support institutions for the development of entrepreneurship whose main purpose is to provide encouragement for the development of the overall business environment and provide the necessary prerequisites for the development of entrepreneurs in a particular area through the provision of consulting services, business space, information and other services. Business incubators are established with the aim of dynamising local and regional economic development, since the target group of incubators are companies from the area of their county or city, which meet the criteria for being accommodated in the incubator. The purpose of this paper is to investigate the role of business incubators in providing support to the small and medium-sized enterprises in the Republic of Croatia. The paper aims to present some of the basic characteristics of business incubators, their determinants and business practices, and to explore and analyse the range of services that incubators provide to their tenants. Also, the paper seeks to explore the basic business objectives, sources of financing, and to analyse the incubators' performance. Empirical data were 
collected through a survey questionnaire on a sample of 34 business incubators. The method of descriptive statistical analysis was used as the analytical method because the primary goal of this paper is to provide a detailed description of the current state, characteristics and operations of business incubators in the Republic of Croatia, and not to determine mutual dependencies or causalities between the observed variables.

Keywords: business incubators, support institutions, entrepreneurship, Croatia, local and regional development 